\title{
Improving the Learning Results of Indonesian Subject through the Use of Quizizz Media for the Third Graders of Elementary School
}

\author{
Mei Kurnia Fitriani \\ SD Negeri 3 Kebumen \\ fitrianimeikurnia@gmail.com
}

\section{Article History}

accepted 14/11/2020

approved $21 / 11 / 2020$

published 26/11/2020

\begin{abstract}
The purpose of this study is to improve the learning outcomes of the third graders using Quizizz at SD Negeri 3 Kebumen Pringsurat subdistrict Temanggung regency Academic Year 2020/2021. The type of this research is Classroom Action Research (CAR) using Quizizz media with two cycles. Each cycle consists of four stages, namely planning, implementation, observation and reflection. The research subjects are grade III students of SD Negeri 3 Kebumen Pringsurat subdistrict Temanggung regency. Data collection techniques is using tests and observations. Data analysis techniques using quantitative data and qualitative data. Based on the results of the study, the average score of the study results in cycle I is 73,33 and completion of 10 students with a percentage of $55,56 \%$. On the implementation of cycle II measures averaged 78,89 and completed 15 students with a percentage of 83,33\%. The conclusion of this Classroom Action Research is that using Quizizz media can improve the learning outcomes of the third graders of SD Negeri 3 Kebumen.
\end{abstract}

Keywords: classroom action research, study results, quizizz media

\begin{abstract}
Abstrak
Tujuan penelitian ini adalah meningkatkan hasil belajar siswa kelas III menggunakan media Quizizz di SD Negeri 3 Kebumen Kecamatan Pringsurat Kabupaten Temanggung Tahun Pelajaran 2020/2021. Jenis penelitian ini adalah Penelitian Tindakan Kelas menggunakan media Quizizz dengan dua siklus. Setiap siklus terdiri atas empat tahap, yaitu perencanaan, pelaksanaan, observasi dan refleksi. Subjek penelitian adalah siswa kelas III SD Negeri 3 Kebumen Kecamatan Pringsurat Kabupaten Temanggung. Teknik pengumpulan data menggunakan tes dan pengamatan. Teknik analisis data menggunakan data kuantitatif dan data kualitatif. Berdasarkan hasil penelitian, diperoleh nilai rata-rata hasil belajar pada siklus I 73,33 dan ketuntasan sebanyak 10 siswa dengan persentase $55,56 \%$. Pada pelaksanaan tindakan siklus II rata-rata 78,89 dan ketuntasan sebanyak 15 siswa dengan persentase 83,33 $\%$. Simpulan dari Penelitian Tindakan Kelas ini adalah menggunakan media Quizizz dapat meningkatkan hasil belajar siswa kelas III SD Negeri 3 Kebumen.
\end{abstract}

Kata Kunci: penelitian tindakan kelas, hasil belajar, media quizizz

Social, Humanities, and Education Studies (SHEs): Conference Series https://jurnal.uns.ac.id/shes

p-ISSN 2620-9284

e-ISSN 2620-9292 


\section{PENDAHULUAN}

Tahun 2020 merupakan tahun yang berat bagi kita semua. Hingga saat ini di Indonesia masih dilanda pandemi Covid-19. Segala daya dan upaya sudah dilakukan pemerintah guna memperkecil kasus penularan Covid-19. Tak dipungkiri salah satunya adalah kebijakan belajar online atau dalam jaringan (daring) untuk seluruh siswa karena pembatasan sosial. Kebijakan belajar online ini menuntut guru untuk kreatif dalam penyampaian pembelajaran agar siswa mudah memahami pembelajaran secara daring.

Hal ini menjadi tantangan bagi guru untuk dapat menciptakan pembelajaran yang menarik dan menyenangkan. Pembelajaran yang menyenangkan dapat diciptakan melalui penggunaan berbagai macam model atau metode pembelajaran ataupun menggunakan media pembelajaran yang menarik, sehingga membuat siswa menjadi bersemangat untuk belajar dan lebih mudah memahami materi. Pengembangan media pembelajaran menggunakan komputer atau laptop dan handphone atau smartphone, salah satunya dengan pemanfaatan media pembelajaran Quizizz.

Berdasarkan hasil observasi yang dilakukan peneliti di SD Negeri 3 Kebumen, siswa merasa bosan dengan pembelajaran daring karena guru masih menggunakan media Whatsapp Group dalam pemberian tugas. Sehingga siswa malas belajar dan mengakibatkan penurunan hasil belajar. Media Quizizz dapat digunakan oleh guru untuk melihat sejauh mana siswa dalam belajar. Penggunaan yang mudah dan hasil yang cepat dalam proses penilaiannya menjadikan aplikasi ini layak digunakan sebagai aplikasi pembelajaran yang mendukung revolusi pembelajaran 4.0, sehingga siswa memiliki minat dan motivasi yang kuat untuk meningkatkan hasil belajar daring.

Berdasarkan hasil observasi awal yang dilakukan peneliti di SD Negeri 3 Kebumen pada siswa kelas III pada Senin, 26 Oktober 2020. Kemudian peneliti melakukan observasi lanjutan pada Senin, 2 November 2020 dan memperoleh hasil observasi yaitu hasil belajar mupel Bahasa Indonesia yang didapatkan masih rendah, hal ini ditunjukkan pada nilai Ulangan Harian yang sebagian besar siswanya memperoleh nilai di bawah Kriteria Ketuntasan Minimal (KKM) yang ditetapkan sekolah yaitu 70 . Sebanyak 66,67\% (12 dari 18) belum memenuhi Kriteria Ketuntasan Minimal (KKM) dan hanya 33,33\% (6 dari 18) yang sudah memenuhi Kriteria Ketuntasan Minimal (KKM). Dari rata-rata data dokumen nilai guru ditunjukkan dengan nilai terendah 40 dan nilai tertinggi 90 . Penyebab dari pemerolehan nilai tersebut adalah metode pembelajaran yang diterapkan belum menarik dan menyenangkan sehingga anak merasa bosan dan malas mengikuti pembelajaran daring, siswa masih belum optimal dalam pembelajaran daring karena pembelajaran yang diterapkan oleh guru monoton, siswa kurang kreatif dan mandiri karena pengawasan guru dalam pembelajaran daring terbatas, media pembelajaran daring selama ini kurang menarik siswa untuk belajar dan guru belum pernah menggunakan media Quizizz.

Rumusan masalah pada penelitian ini adalah sebagai berikut: Apakah penerapan media Quizizz dapat meningkatkan hasil belajar siswa kelas III semester 1 SD Negeri 3 Kebumen Tahun Pelajaran 2020/2021? Dan tujuan dari penelitian ini adalah untuk mengetahui peningkatan hasil belajar siswa melalui penggunaan media Quizizz pada siswa kelas III semester 1 SD Negeri 3 Kebumen Tahun Pelajaran 2020/2021. Penelitian ini terdiri dari 2 siklus. Subjek dalam penelitian ini adalah siswa kelas III SD Negeri 3 Kebumen yang berjumlah 18 siswa dengan karakteristik yang heterogen. Hasil penelitian menunjukkan adanya peningkatan rata-rata hasil belajar mupel Bahasa Indonesia. Pada kondisi awal nilai rata-rata siswa yaitu 61,89 dengan persentase ketuntasan $33,33 \%$. Pada pembelajaran siklus I dengan menggunakan media Quizizz, nilai rata-rata siswa meningkat menjadi 73,33 dengan persentase ketuntasan 55,56\%. Pada pembelajaran siklus II nilai rata-rata siswa 78,89 dengan 
persentase ketuntasan $83,33 \%$. Dengan demikian dapat disimpulkan bahwa menggunakan media Quizizz dapat meningkatkan hasil belajar mupel Bahasa Indonesia siswa kelas III semester 1 SD Negeri 3 Kebumen Tahun Pelajaran 2020/2021.

\section{METODE}

Jenis penelitian yang dipilih adalah Penelitian Tindakan Kelas (PTK). Siklus I dilaksanakan pada 26 Oktober-4 November 2020. Dilanjutkan siklus II pada 5 November-11 November 2020.

Subjek penelitian ini adalah siswa kelas III SD Negeri 3 Kebumen semester 1 Tahun Pelajaran 2020/2021 yang berjumlah 18 siswa. Terdiri dari 10 siswa perempuan dan 8 siswa laki-laki. Teknik dan Alat Pengumpulan Data. Tes dalam bentuk pilihan ganda, isian dan uraian. Peneliti mengobservasi siswa selama proses pembelajaran berlangsung. Pada penelitian ini, alat pengumpulan data yang digunakan untuk mengukur penggunaan media Quizizz untuk meningkatkan hasil belajar mupel Bahasa Indonesia kelas III adalah melalui lembar pengamatan dan didukung oleh dokumen berupa foto dan video pelaksanaan pembelajaran. Teknik analisis data dilakukan secara kuantitatif dan kualitatif. Data kuantitatif diperoleh dari penilaian tes pada siklus I dan siklus II. Hasil dari penelitian ini memberikan deskripsi adanya peningkatan hasil belajar menggunakan media Quizizz. Setelah mengumpulkan data kualitatif melalui observasi, hasil dari analisis data digunakan untuk mengetahui perubahan sikap siswa yaitu keaktifan dalam pembelajaran pada siklus I dan siklus II.

\section{HASIL DAN PEMBAHASAN}

Pembelajaran siklus I dilaksanakan pada hari Senin, 2 November 2020 dengan objek penelitian siswa kelas III SD Negeri 3 Kebumen Kecamatan Pringsurat Kabupaten Temanggung dan dibantu oleh guru mitra yang bertindak sebagai pengamat selama proses pembelajaran berlangsung. Pencapaian hasil belajar siswa pada pembelajaran siklus I disampaikan melalui tabel rekapitulasi hasil belajar sebagai berikut:

Tabel 1. Hasil Tes Formatif Pembelajaran Siklus I

\begin{tabular}{llcccc}
\hline No & \multicolumn{1}{c}{ Nama Siswa } & KKM & Nilai & Tuntas & $\begin{array}{c}\text { Belum } \\
\text { Tuntas }\end{array}$ \\
\hline 1. & Afrida Inas Lasca & 70 & 60 & & $\sqrt{ }$ \\
2. & Assidiq Edo Sobirin & 70 & 60 & & $\sqrt{ }$ \\
3. & Faisal Izzul Haq & 70 & 60 & & $\sqrt{ }$ \\
4. & Gita Dewiyana & 70 & 100 & $\sqrt{ }$ & \\
5. & Grivin Adriano & 70 & 70 & $\sqrt{ }$ & \\
6. & Hafiza Mahta Khaira & 70 & 100 & $\sqrt{ }$ & \\
7. & Indri Muntiyasari & 70 & 70 & $\sqrt{ }$ & \\
8. & Kurniawan Rizki P. & 70 & 50 & & $\sqrt{ }$ \\
9. & Lydia Evania & 70 & 90 & $\sqrt{ }$ & \\
\hline
\end{tabular}




\begin{tabular}{|c|c|c|c|c|c|}
\hline 10. & M. Vicko Alfaris & 70 & 80 & $\sqrt{ }$ & \\
\hline 11. & Nizam Afiif Muzakki & 70 & 80 & $\sqrt{ }$ & \\
\hline 12. & Nur Utami & 70 & 60 & & $\sqrt{ }$ \\
\hline 13. & Reva Dwi Syalikha & 70 & 40 & & $\sqrt{ }$ \\
\hline 14. & Rizqi Landung Y. & 70 & 100 & $\sqrt{ }$ & \\
\hline 15. & Salwa Arum Noviana & 70 & 90 & $\sqrt{ }$ & \\
\hline 16. & Syamsul Huda & 70 & 60 & & $\sqrt{ }$ \\
\hline 17. & Ika Dewi Wahyu Ningsih & 70 & 90 & $\sqrt{ }$ & \\
\hline 18. & Hilma Nur Aini & 70 & 60 & & $\sqrt{ }$ \\
\hline \multicolumn{3}{|c|}{ Jumlah } & 1.320 & 10 & 8 \\
\hline $\begin{array}{l}\text { Nilai } \\
\text { Nilai } \\
\text { Nilai } \\
\text { Ting }\end{array}$ & $\begin{array}{l}\text { ata-rata } \\
\text { ertinggi } \\
\text { erendah } \\
\text { at ketuntasan kelas }\end{array}$ & $\begin{array}{l}=73,33 \\
=100 \\
=40 \\
=55,56 \%\end{array}$ & & & \\
\hline
\end{tabular}

Dari hasil data di atas dapat disimpulkan bahwa siswa yang mendapat nilai sesuai KKM sebanyak 10 siswa dengan persentase ketuntasan 55,56 \%. Sedangkan siswa yang belum mencapai KKM sebanyak 8 siswa dengan persentase $44,44 \%$.

Perbaikan pembelajaran siklus II ini dilaksanakan pada hari Senin, 9 November 2020 dengan objek penelitian siswa kelas III SD Negeri 3 Kebumen Kecamatan Pringsurat Kabupaten Temanggung dan dibantu oleh guru mitra yang bertindak sebagai pengamat selama proses pembelajaran berlangsung. Pencapaian hasil belajar siswa pada perbaikan pembelajaran siklus II disampaikan melalui tabel rekapitulasi hasil belajar sebagai berikut:

Tabel 2. Hasil Tes Formatif Perbaikan Pembelajaran Siklus II

\begin{tabular}{llcccc}
\hline No & \multicolumn{1}{c}{ Nama Siswa } & KKM & Nilai & Tuntas & $\begin{array}{r}\text { Belum } \\
\text { Tuntas }\end{array}$ \\
\hline 1. & Afrida Inas Lasca & 70 & 70 & $\sqrt{ }$ & \\
2. & Assidiq Edo Sobirin & 70 & 70 & $\sqrt{ }$ & \\
3. & Faisal Izzul Haq & 70 & 80 & $\sqrt{ }$ \\
4. & Gita Dewiyana & 70 & 100 & $\sqrt{ }$ \\
5. & Grivin Adriano & 70 & 80 & $\sqrt{ }$ \\
6. & Hafiza Mahta Khaira & 70 & 100 & $\sqrt{ }$ \\
7. & Indri Muntiyasari & 70 & 80 & $\sqrt{ }$ \\
\hline
\end{tabular}




\begin{tabular}{|c|c|c|c|c|c|}
\hline 8. & Kurniawan Rizki P. & 70 & 60 & & $\sqrt{ }$ \\
\hline 9. & Lydia Evania & 70 & 100 & $\sqrt{ }$ & \\
\hline 10. & M. Vicko Alfaris & 70 & 80 & $\sqrt{ }$ & \\
\hline 11. & Nizam Afiif Muzakki & 70 & 80 & $\sqrt{ }$ & \\
\hline 12. & Nur Utami & 70 & 70 & $\sqrt{ }$ & \\
\hline 13. & Reva Dwi Syalikha & 70 & 50 & & $\sqrt{ }$ \\
\hline 14. & Rizqi Landung Y. & 70 & 100 & $\sqrt{ }$ & \\
\hline 15. & Salwa Arum Noviana & 70 & 80 & $\sqrt{ }$ & \\
\hline 16. & Syamsul Huda & 70 & 80 & $\sqrt{ }$ & \\
\hline 17. & Ika Dewi Wahyu Ningsih & 70 & 80 & $\sqrt{ }$ & \\
\hline 18. & Hilma Nur Aini & 70 & 60 & & $\sqrt{ }$ \\
\hline & Jumlah & & & 15 & 3 \\
\hline
\end{tabular}

$\begin{array}{lll}\text { Nilai rata-rata } & =78,89 \\ \text { Nilai tertinggi } & =100 \\ \text { Nilai terendah } & =50 \\ \text { Tingkat ketuntasan kelas } & =83,33 \%\end{array}$

Dari hasil data di atas dapat disimpulkan bahwa siswa yang mendapat nilai sesuai KKM sebanyak 15 siswa dengan persentase ketuntasan 83,33 \%. Sedangkan siswa yang belum mencapai KKM sebanyak 3 siswa dengan persentase 16,67\%. Secara lengkap peningkatan ketuntasan tersebut terlihat pada tabel berikut.

Tabel 3. Peningkatan Ketuntasan Pemahaman Siklus I dan Siklus II

\begin{tabular}{clcc} 
No & \multicolumn{1}{c}{ Kriteria } & Siklus I & Siklus II \\
\hline 1. & $\begin{array}{l}\text { Jumlah siswa yang tuntas } \\
\text { (memenuhi KKM) }\end{array}$ & 10 & 15 \\
2. & Persentase Ketuntasan & $55,56 \%$ & $83,33 \%$
\end{tabular}

Perbandingan di atas, memperlihatkan belum berhasil perbaikan pada siklus II. Perlu dilakukan perbaikan di siklus III.

\section{SIMPULAN}


Berdasarkan hasil penelitian materi Keajaiban Perubahan Wujud di Sekitarku mupel Bahasa Indonesia menggunakan media Quizizz pada siswa kelas III SD Negeri 3 Kebumen Kecamatan Pringsurat Kabupaten Temanggung dan pembahasan yang disajikan pada bab IV dapat ditarik simpulan sebagai berikut: Penggunaan media Quizizz pada materi Keajaiban Perubahan Wujud di Sekitarku mupel Bahasa Indonesia kelas III SD Negeri 3 Kebumen dapat meningkatkan keaktifan siswa. Peningkatan keaktifan siswa terlihat dengan menyiapkan belajar tepat waktu, keterlibatan siswa dalam pembelajaran mulai aktif, kemampuan menjawab pertanyaan guru meningkat, aktif menyampaikan pendapat dan bertanya pada guru. Penggunaan media Quizizz pada materi Keajaiban Perubahan Wujud di Sekitarku mupel Bahasa Indonesia kelas III SD Negeri 3 Kebumen dapat meningkatkan hasil belajar siswa. Peningkatan hasil belajar siswa terlihat dengan meningkatnya hasil belajar siswa dari siklus I tuntas 55,56 $\%$, pada siklus II meningkat menjadi 83,33\%.

\section{DAFTAR PUSTAKA}

Arikunto, dkk. (2015). Penelitian Tindakan Kelas. Jakarta: Bumi Aksara.

Kusuma, Wijaya. (2012). Mengenal Penelitian Tindakan Kelas. Jakarta: Indeks.

Mulyatiningsih, Endang. (2014). Metode Penelitian Terapan. Bandung: Alfabeta.

Sudjana, Nana. (2010). Dasar-Dasar Proses Belajar Mengajar. Bandung: Sinar Baru Argesindo.

Aini, YI. (2019). Pemanfaatan Media Pembelajaran Quizizz untuk Pembelajaran Jenjang Pendidikan Dasar dan Menengah di Bengkulu. Diakses 8 Oktober 2020 dari http://jurnal.umb.ac.id/index.php/kependidikan/article/view/567

Nurhayati, E. (2020). Meningkatkan Keaktifan Siswa Dalam Pembelajaran Daring Melalui Media Game Edukasia Quizizz Pada Masa Pencegahan Penyebaran Covid-19. Diakses $8 \quad$ Oktober 2020 dari

http://139.59.120.216/index.php/pedagogy/article/view/26 